\title{
Valuation of intangible assets according to Czech accounting standards and IFRS in the context of explanatory power of financial statements
}

The globalization of the economy and the levelling of the boundaries in entrepreneurial activity necessitates the international comparability of corporate financial reports in order to make effective management decisions by banks, business partners, rating agencies and other. The article addresses possible changes in company's creditworthiness, represented by the change in the achieved values of the Z-score bankruptcy model as a result of data application from the IFRS financial statements as compared to the data from the reports compiled according to the Czech Accounting Standards. The intention has been to highlight the possible deterioration in its creditworthiness. This article aims at mapping out the differences between the two modifications in the area of acquisition and valuation of fixed assets in the selected segment of construction companies and demonstration of their impact on the explanatory power of financial statements prepared in accordance with the Czech Accounting Standards and IFRS. The article also identifies the risks that this situation brings to users of accounting statements. When using the data of 20 financial statements of entities with main activity in the construction sector lower values were achieved for the Z-score indicators compiled from the IFRS statements as compared to the values determined with the use of data from financial statements prepared according to the Czech Accounting Standards. The main reasons for this impact are the differences in the procedures for discounting of assets values to present value and accounting for the lease which may lead to significant differences in the financial performance of the company, levels of its financial stability and market value. It is proved that these differences can have a certain risk for the portfolio of companies credited by one bank.

Keywords: bankruptcy model, IFRS, Czech Accounting Standards, Z-score model, financial statements, valuation of assets.

Introduction. The global character of the world economy brings the requirements of stakeholders, especially investors, banks, rating agencies and other entities, to the international comparability of corporate financial statements. Logically, the need for national and international consistency in the application of accounting standards is growing. Financial statements are the main source of information on the prosperity and performance of companies and their financial stability (Dlaskova, 2013).

In the Member States of the European Union the process of accounting standards' harmonization is still ongoing, and the International Financial Reporting Standards (hereafter IFRS) is its key instrument. The result of this process should be so long-time awaited harmonization of national accounting legislations with the IFRS accounting standards and, ultimately, elimination or at least radical reduction of distrust in the explanatory power of financial statements. The area of tangible assets in Czech accounting is the one that displays significant differences when compared to IFRS modification, and it is particularly analyzed in this article. Another aim of this article is to map the differences between the two adjustments in the area 
of acquisition and valuation of long-term assets in the selected segment of construction companies and to demonstrate their impact on the explanatory power of financial statements prepared in accordance with the Czech Accounting Standards (hereafter CAS) and IFRS. The explanatory power is demonstrated here by a possible deterioration in company's creditworthiness as a result of the use of financial statements prepared in accordance with the IFRS. In connection with these impacts, the article identifies the risks that this situation brings to users of financial statements.

Valuation of assets according to the IFRS and according to the Czech Accounting Standards still has significant differences that affect the amount of the balance sheet, the structure of assets, influencing the amount of costs and hence the amount of profit. Differences in valuation and reporting then result in very significant differences $t$ reflected in financial statements, which are the basic sources of accounting data. In this so-called double reporting, there arise the differences between the financial statements under the IFRS and the CAS. "If this is not the case, even if such a case can occur in a situation where the company only shows the elements that are consistent in both systems, the two accounting systems would have to be identical and then the whole of this double reporting process would be nonsense. It follows that there is already a significant number of interconnection points between the basic principles of the IFRS and Czech accounting legislation, but significant differences between individual sub-principles still persist (some issues are not even dealt with in Czech law at all). These are the ones that then have a significant impact on financial statements" (Dlaskova, 2013).

Methodologically, the article is based mainly on the comparison of the values of the absolute indicators in financial statements compiled according to the CAS and IFRS, for the sample of 20 randomly selected construction companies and further their transfer to the bankruptcy model called Z-SCORE.

Literature review. The aim of today's modern reporting is therefore logically to provide information for effective decision-making to investors and other interested groups that will allow and simplify access to capital markets by their quality and ease of comparability, as noted by Krupová (2009). As a result, there are, of course, increasing pressures on the harmonization of financial reporting systems (Krupová, 2009).

The European Union has begun in its member states the process of harmonizing accounting standards, resulting in the alignment of national accounting legislation with IFRS accounting standards. However, IFRS is not omnipotent and its implementation cannot be expected to be the unique and only solution to the problem, because even the individual standards are just the result of the consensus of many creators, their opinions and ideas, and provide some "creative" freedom to accounting entities when using them. Accounting expert Robert Mladek (2011), in the article "IFRS 10: Win Principles, New Rules for Consolidation", discussing about the fact that part of the management of large companies is trying to invent ways to evade accounting rules. However, as per the author, it is crucial to say that, according to estimates, up to $20 \%$ of managers are concerned with how to "crush traces of their incorrect, irresponsible or simply stupid behavior." Mládek, R.: IFRS 10: zásady vítězí, Nová pravidla pro konsolidace, Wolters Kluwer ČR, a. s. 2011/9. It is specifically them who have the most influence on the development of IFRS and are one of the main reasons for the broadness of these standards, especially in the part of disclosure, which, among other things, has the task of limiting the ability of managers to act in violation of fundamental principles.

IFRS has long been addressed by the following authors. Czech National Bank's senior expert Jilek (2013) notes that the accounting rules are getting "softer", mainly because accounting allows overvaluation of assets and understatement of liabilities. According to Mládek, Accounting Officer (2011), IFRS is not omnipotent and since its implementation, it is not possible to expect the unique and only solution to the problem, because even the individual standards are the result of the consensus of many creators, their opinions and ideas, and they provide some "creative" freedom to the accounting entities.

The asset valuation area is also being investigated for a long time by author Krupová (2009), which states that it is perhaps exactly the area, where in practice appear the most mistakes and inaccurate 
interpretations of IFRS requirements. According to this author, in particular, it refers to the nondifferentiation of situations where an intangible asset is acquired in connection with a business combination under IFRS 3 and when an intangible asset is treated in accordance with IAS 38 Intangible Assets. Also, a prominent expert with dedicated publications in this area is Strouhal (2013), the author which brings attention to the impact of various valuation models and procedures on selected financial indicators.

The default literature for this work is also International Financial Reporting Standards (IFRS) in its entirety, as well as publications of Dana Dvořáková, Financial Accounting and Reporting in Accordance with International Standards IFRS (2nd Updated and Extended Edition), which includes IFRS amendments valid from January 1, 2009 and the publications by Eva Sládková et al., Financial Accounting and Reporting, which deals with the most used standards in practice.

Methodology. From a methodological point of view the basis for this article is a combination of several sources. The first and dominant source is the financial statements obtained from 20 construction companies which applied the Z-score bankruptcy model on them. Other sources are International Financial Reporting Standards and Czech Accounting Standards in the current version, whose analysis and comparison identified the most important differences between the two adjustments.

The selection of the analysed companies was mainly based on the availability of financial statements. The first problematic issue in the selection process was the fact that domestic companies registered in the Commercial Register, which are legally obliged to publish the financial statements in the collection of documents, do not always do so. The second problem while selecting companies, which further narrowed the already limited selection, was the absence of the so-called second set of IFRS-compiled statements. The above complications have led to a reduction in the selection of suitable businesses and only 20 compliant companies from the construction business have been selected.

The issue of international standards is extremely extensive and the asset area creates more than half of these standards. For most of them, the impact of the valuation is not so significant that it is relevant to this article, or that the company encounters it very rarely in practice. Therefore, this article deals mainly with the valuation and revaluation of selected long-term assets, where the different valuation and posting methodologies can result in very significant differences. The most striking are these differences, for example, in the area of construction that has been selected for exploration.

Results and discussions. IFRS accurately defines assets and in accounting the assets are accounted for only if they meet this definition. These are sources arising from the past events, and they are measurable, controlled by the accounting entity and reported when it is probable that they will yield economic benefits, i.e. it does not matter whether the entity is the owner of the asset or a mere lessee and is at the sole discretion of the accounting entity to recognize that the asset qualifies for recognition and reporting. The CAS does not know the concept of asset recognition and there is no definition for it, in the law the individual types of assets are enumerated and included in the relevant groups, except for isolated cases owned by the unit, otherwise they cannot be reported, which is one of the differences between the two approaches.

Czech Accounting Standards require three mandatory parts of the financial statements - balance sheet, income statement and notes. According to IFRS, the financial statements have five mandatory parts - the balance sheet, the income statement, the statement of cash flows, the statement of changes in equity and the commentary, and only set the mandatory components of the statements. Further in IFRS the terms of recognition, valuation and reporting for each of the accounts are reviewed in detail. The exact conditions under which an asset or liability can be recognized are determined. This situation is dealt with in the CAS by the exhaustive appointment of items that fall within the individual parts of the financial statements in Decree No. 500/2002 Coll. Profit / loss statement is a mandatory part of both financial statements. The CAS regulates the arrangement and marking of individual items, but the general conditions for recognition 
are not specified. According to IFRS, the exact structure of the income statement is not set, but the items are prescribed that must obligatorily contain this statement. The comment is also a mandatory part of the financial statements according to both IFRS and the CAS (Annex).

Reporting of fixed assets

When an asset is measured at the time of acquisition, the cost of an asset under IFRS also includes the estimated costs associated with the asset's disposal and is depreciated as part of the cost. The revaluation model uses overvalued asset values and frequent revaluations of fixed assets are necessary. According to the CAS, however, the cost of dismantling, removal costs and the cost of restoring the original conditions are not included in the valuation. Interest expense (borrowing costs) during the construction of fixed assets is capitalized if the accounting entity decides so. After the asset is put into use, the activated interest expense is depreciated over the useful life of the asset.

Other significant differences can be found, for example, in the coding approach. When depreciating tangible fixed assets under IFRS, a component approach applies, each item of property, buildings and equipment, the cost of which is significant in relation to the asset's fair value, must be depreciated separately. According to Czech Accounting Standards, the asset is depreciated as a whole, and according to IFRS, for example, all spare parts are not classified as inventories, but major spare parts are directly included in the item of property, buildings and equipment and amortized. According to the CAS, spare parts are classified as stocks and enter into costs during consumption. Czech Accounting Standards require, in line with the principle of prudence, as well as IFRS, to capture impairment of assets. However, there is a significant difference in how to find out if that happened. Czech Accounting Standards require a simple comparison of the net book value and the current market price of the asset, i.e. they do not take into account the value of the utilization and do not require its collateral, as opposed to IFRS. The CAS creates a provision for the temporary decrease of the asset's value and the asset is permanently impaired by means of allowances. IFRS does not distinguish between temporary and permanent impairment of an asset.

Reporting of leasing. Leasing is a very significant difference between the two systems. Reporting of a lease in IFRS is based on the principle of the preference of the content before the form. Therefore, if the lease is merely a special form of financing the asset acquisition (financial leasing), since the most important criterion for distinguishing between financial and operating leases is whether the risks and benefits associated with the asset are transferred to the lessee, it is recorded as the acquisition of the asset and the long-term liability in the balance of the lessee and, of course, the lessee will also depreciate it. The lease liability under IFRS is initially equal to the fair value of the leased asset or the present value of the minimum lease payments and is subsequently reduced by the lease payments. The landlord does not account for the leased asset as its property and does not depreciate it. It only manages a leasing claim, which should be in the amount of costs associated with asset management and is continuously reduced by the paid lease payments. The lessor's share of the lease payments is accounted for as interest.

On the other hand, Czech Accounting Standards do not respect the principle of the preference of content before the form and do not respect as well as do not allow reporting of the leased asset. They distinguish the lease based on the legal form of the leasing contract and the fact whether the leased property is leased to the lessor at the end of the lease term and that the finance lease is treated as a longterm lease of the asset, which, of course, leads to a distortion of the explanatory power of the financial statements. Therefore, it is necessary to "modify the financial statements prior to the financial analysis with the items related to the leasing" (Dvoráková, 2008). The asset is kept only in the off balance sheet records and is not depreciated. The lease is accounted for in accrual principles (usually the first incremental installment) with the subsequent dissolution into costs. Other payments are treated as operating liabilities. As a result of the above-mentioned procedure, there also appears different amount of operating and financial income, when using IFRS. The lessor charges in its assets the leased assets and 
depreciates them. The first increased installment is accounted for in the accruals of liabilities with the gradual dissolution into revenue. Then the proceeds are leasing installments.

Reporting of reserves. Understanding of reserves is similar in both systems, yet there are several significant differences between IFRS and Czech Accounting Standards. One of them in the Czech law's legal reserves is based on the so-called legal reserves created with regard to the future costs of repairs of tangible fixed assets. The creation and use of these reserves is governed by the Reserve Act and their creation is not limited by the general accounting definition of the reserve. Here again, there is a must to recall the high degree of influence by the tax laws, and only the creation of these statutory reserves is a tax-deductible expense. Such reserves are not permitted in IFRS, they are not recognized as future liabilities under IFRS and therefore are not reported in accordance with IAS 37, Reserves, Contingent Liabilities, and Contingent Assets.

Furthermore, the issue of liabilities related to the present value of the costs of dismantling, removal or restoration resulting from legal or contractual obligations is not resolved in the Czech legislation. In practice, there are multiple ways of accounting for liabilities from removing assets. The carrying amount of tangible fixed assets cannot be increased as a result of the creation or change in liabilities from removing of assets. In addition, for businesses, the area of discounted reserves is not being dealt with at the present value, and therefore some units have undiscounted reserves.

Method of valuation of assets and their subsequent accounting treatment in accordance with IFRS therefore shows differences from valuation and accounting in accordance with the CAS and thus affects the amount of the economic result, its cost structure, but also the amount and structure of the assets themselves. The resulting financial statements have logically different explanatory power and value than the financial statements prepared in accordance with Czech Accounting Standards. This situation brings another picture of the same company in the assessment of financial health and stability using methods of financial analysis according to the accounting statements generated as outputs of different accounting systems, and it is therefore crucial to identify the system in which the financial statements were created, i.e. source of accounting data.

Different reporting of leases in both systems have the most significant impact on the amount and structure of assets as well as liabilities. Czech Accounting Standards do not allow the recognition of longterm lease liabilities in the financial statements, which has a significant effect on, for example, debt ratios. When performing financial analyses, the value of this indicator is distorted. In addition, the explanatory power of all the indicators for which the sum of total or long-term assets is used is calculated. As a result of the different lease reporting, there is also a different amount of depreciation (cost), which may lead, for example, to a complete misstatement of an enterprise's valuation when the enterprise is valued by the discounted cash flow method. In the calculation, the depreciation level and the change in payables are decisive (Dlaskova, Havlicek, 2013).

Discounting asset values to the current IFRS value also affects the amount of the financial result (e.g. deferred payment). The CAS does not demand such discounting, except for financial institutions, as a result of which, for example, calculations may lead to significant differences between the values of the cost of foreign capital and the related indicators. Of all the above circumstances, it is clear that the financial statements prepared in accordance with IFRS and the results of the financial analysis based on it "will provide a different picture about the company's profit, its financial stability, but also its market value than the "Czech" financial statements". This different explanatory power of financial statements should therefore be considered by the users of financial statements, especially investors, banks and other creditors.

A suitable tool for demonstrating the above differences is financial analysis, which works with absolute (itemized) indicators, with differential and relative indicators established from the individual items of financial statements, so-called one-dimensional models. For the purposes of this article, however, it seems 
most appropriate to use one of the multidimensional models, "which represent a combination of weights of the individual most proficient indicators with the greatest explanatory power. The value that was set in such a way, with some probability, should tell what would be the expected development of the business" (Lánský, Kotěšovcová, Dlasková, 2014).

These models are referred to as bankruptcy models. The Z-score model (by author E. I. Altman), which is modified for the purposes of the model's application in a company without public offer of shares, was selected. The main adjustment of the model is in replacement of the "market value of equity / total liabilities" with the indicator "net book value of equity / total capital".

Altman's Z-score model has the following form:

$$
\mathrm{Z}=0,717 \times \frac{\mathrm{WC}}{\mathrm{A}}+0,847 \times \frac{\mathrm{RE}}{\mathrm{A}}+3,107 \times \frac{\mathrm{EBIT}}{\mathrm{A}}+0,420 \times 0 \mathrm{E} / \mathrm{C}+0,998 \times \mathrm{S} / \mathrm{A}
$$

where WC - working capital; A - total assets; RE - retained earnings; EBIT - Earnings before interest and tax; OE- book value of equity; $\mathrm{C}$ - total capital; $\mathrm{S}$ - Sales.

If the value of the Z-score model is greater than 2.9 , the accounting entity is in a zone of prosperity. A value greater than 1.23 and less than 2.9 classifies a unit in the so-called grey zone where it is unclear to determine whether the company will go towards prosperity or will be threatened in the near future by bankruptcy. A value less than 1.23 clearly indicates that the entity is at risk of bankruptcy.

Analysis. For the analysis, 20 financial statements of entities with main activity in the construction sector have been used. In this sector, it is possible to assume a high proportion of financing through leasing assets, use of deferred payments, etc. The differences between the values of the selected Z-score model according to IFRS and CAS should therefore be clearly demonstrated.

Table 1 shows the cost items associated with the acquisition of the long-term assets (DM) of all selected companies reported in the financial statements prepared under IFRS and subsequently the values in the financial statements prepared under the CAS.

The table shows distinct differences in recognition of depreciation charges, the different settlement of leases and the recording of borrowing costs. Total costs are lower by $18 \%$ according to IFRS.

Table 1 - Cost structure and impact on the result of operations according to IFRS and CAS (Own processing)

\begin{tabular}{|l|c|c|}
\hline $\begin{array}{c}\text { Structure of costs associated } \\
\text { with acquisition of DM }\end{array}$ & IFRS in millions of CZK & CAS in millions of CZK \\
\hline Depreciation & 10248 & 4972 \\
\hline Leasing interest & 357 & 0 \\
\hline Rent (leasing) & 0 & 6719 \\
\hline Creating a reserve & 0 & 2440 \\
\hline Interest rate reserve & 322 & 0 \\
\hline Decrease in asset value & 705 & 705 \\
\hline Borrowing costs & 957 & 0 \\
\hline Total costs & $\mathbf{1 2 5 8 9}$ & $\mathbf{1 4 8 3 6}$ \\
\hline Impact on profit / loss & $\mathbf{- 1 2 5 8 9}$ & -14836 \\
\hline
\end{tabular}

Table 2 identifies the values of selected balance sheet items of all selected companies reported in the financial statements prepared under IFRS and subsequently the values in the financial statements prepared under the CAS. The items that are important for calculating the value of Z-score model indicator 
were selected. The table clearly shows marked differences in the total assets, equity and long-term liabilities.

Table 2 - Balance sheet items and their values according to IFRS and CAS (own processing)

\begin{tabular}{|l|c|c|}
\hline Balance sheet item & $\begin{array}{c}\text { Valuation and recognition under } \\
\text { IFRS in mil. CZK }\end{array}$ & $\begin{array}{c}\text { Valuation and recognition under } \\
\text { CAS in mil. CZK }\end{array}$ \\
\hline Long-term assets & 64273 & 49642 \\
\hline Short-term assets & 57038 & 57038 \\
\hline Own equity & 12411 & 10164 \\
\hline Long-term liabilities & 19824 & 7440 \\
\hline Undivided profit & 10458 & 8475 \\
\hline EBIT & 1953 & 1689 \\
\hline
\end{tabular}

The percentage expression of all the observed differences is shown in Table 3, considering that the values of the items of the financial statements according to the CAS represent the basis $(100 \%)$ from which we calculate the percentage change of the value. The table is supplemented by revenue, which is also an entry for calculating of the value of Z-score model indicator. According to the CAS the sum of the total revenues of all companies was CZK 16,525 million and, according to IFRS, CZK 14,542 million.

\section{Table 3 - Percentage expression of the value of IFRS items compared to the CAS*}

(Own processing)

\begin{tabular}{|l|c|}
\hline Item & IFRS \\
\hline Long-term assets & $123 \%$ \\
\hline Short-term assets & $100 \%$ \\
\hline Total assets & $123 \%$ \\
\hline Own equity & $116 \%$ \\
\hline Long-term liabilities & $162,50 \%$ \\
\hline Profit / loss & $118 \%$ \\
\hline Revenue & $88 \%$ \\
\hline
\end{tabular}

* We consider that the values of individual items according to the CAS are $100 \%$.

Effects of changes to the Z-score model in the table 4.

Table 4 - Calculating the Z-score model value (Own processing)

\begin{tabular}{|l|c|c|c|c|c|c|}
\hline & WC/A & NZ/A & EBIT/A & OE/C & S/A & Z-SCORE \\
\hline IFRS & 0,636 & 0,138 & 0,093 & 0,042 & 0,226 & $\mathbf{1 , 1 3 5}$ \\
\hline CAS & 0,823 & 0,144 & 0,093 & 0,039 & 0,329 & 1,428 \\
\hline
\end{tabular}

The values of the individual sub-indicators calculated according to the IFRS financial statements show a significant decrease in the values of the individual sub-indicators compared to the results calculated from the reports prepared according to the CAS. The total value of the Z-score model indicator varies according to IFRS in the zone of bankruptcy. According to CAS, we find ourselves in the so-called grey zone. For example, for the portfolio of companies credited by one bank, this could be a certain risk.

Conclusion. On the basis of the findings, it can be concluded that the accounting system under which the financial statements were drawn up can have a significant impact on the assessment of the company's creditworthiness, in this case represented by the achieved values of the Z-score bankruptcy model. Very 
different values of the model can be achieved in sectors where there are significant differences between accounting systems, i.e. there are items that are valued or otherwise recognized in both systems, a typical example of which is the construction sector as it was described above. From the achieved values, it can be assumed that the use of IFRS financial statements may lead to a deterioration in the creditworthiness of the rated entity as a result of a decrease in the value of the Z-score model.

The most significant impact, both on the amount of the change in economic result and on the amount of change and on the structure of assets and liabilities, is expected to be a different accounting for the lease. In international comparison, for these reasons, in some cases, the financial statements are firstly being "cleaned up" from any leases. Czech accounting regulations do not allow literally to recognize longterm lease liabilities in accounting. When performing financial analyses, there is a significant distortion, for example, from the indebtedness indicator. It also reduces the explanatory power of all indicators for which the sum of total or long-term assets is used. The amount of the change in profit or loss may also affect the reporting of provisions. It is problematic by itself to designate, if according to CAS, this is a reserve at all. For example, in various professional publications it is stated that the issue of liabilities related to the present value of the costs of dismantling, removal or restoration arising from statutory or contractual obligations is not solved in Czech accounting regulations and there are various accounting practices in Czech accounting, showing various ways of accounting for an asset disposal obligation, e.g. an IFRS reserve for the disposal of an asset, and the return of the asset to its original condition corresponds to our reserve created for possible risks and expected losses and is also accounted for this way. It also depends very much on the entity, or on the auditor's experience, on its willingness to adapt its accounting practice to possible changes and its sufficient knowledge of whether its financial statements will provide a realistic picture of the company's situation.

A significant influence on the emergence of differences in the amount of profit has also discounting of assets values to present value (e.g. Deferred payment). The CAS does not demand such discounting, except for financial institutions, as a result of which, for example, calculations may lead to significant differences between the values of the cost of foreign capital and the related indicators.

It follows from all the above conclusions that the IFRS financial statements and their analysis will provide a picture different from that of the "Czech" financial statements on the company's financial performance, its financial stability and its market value. This different explanatory power of financial statements is, of course, very irritating, for example, for investors who call for speeding up the harmonization process. They are not the only users of the financial statements, of course, but here also belong the banks, business partners and, last but not least, business managers who need to make a meaningful comparison of the company's situation with the competitors.

Acknowledgment. This academic text is dedicated to the project of the internal grant agency of VŠFS a.s., Prague.

Dlasková, G., Havliček, K. Approach to Valuation of Assets in Czech Accounting, Comparison to IFRS and Impacts on Controlling Process of SME's. In Douček, P., Chroust G., Oškrdal, V (eds).. 21st Interdisciplinary Information Management Talks (IDIMT). Linz, Austria: Johannes Kepler Universität, 2013. s. 343-350, 8 s. ISBN 978-3-99033-083-8.

Dlasková, G. Jste prǐpraveni na možnou změnu bonity vaší firmy v očích vaší banky? Moderní rízení, Praha: Economia, 2013, roč.XLVIII, č. 1, s. 30-30. ISSN 0026-8720.

Dvořáková, D. 2008. Finanční účetnictví a výkaznictví podle mezinárodních standardů IFRS. Druhé, doplněné a aktualizované vydání. Brno: Computer Press, a.s., 2008. ISBN 978-80-251-1950-1.

JíLEK, J., SVOBODOVÁ, J. 2013. Účetnictví podle mezinárodních standardů účetního výkaznictví 2013. Praha: Grada Publishing, a.s. ISBN 80-2474-710-3. 5721.

Kolektiv Autorů. 2006. Mezinárodní standardy účetniho výkaznictví (IFRS) 2005. Praha: Svaz účetních. 2006. ISBN 80-239-

Krupová, L. a kol. 2009. IAS/IFRS Mezinárodní standardy účetního výkaznictví. Praha: VOX, 2009. ISBN 978-80-86024-76-0. Lánský, J., Kotěšovcová, J. a DLASKOVÁ, G. Vyplněnost položek účetních závěrek u akciových společností podle odvětvi CZ- 
Nace. In Hradecké ekonomické dny 2015, díl II. Hradec Králové: Gaudeamus, 2015. s. 114-122, 9 s. ISBN 978-80-7435-547-9.

Mládek, R. 2005. Světové účetnictvi IFRS US GAAP. 3. aktualizované a přepracované vydání. 1.díl. Praha: Linde Praha, a.s. 2005. ISBN 80-7201-519-2.

Ryneš, P. 2004. Podvojné účetnictví a účetní závěrka. Ostrava: ANAG. 2004. ISBN: 80-7263-204-3.

Sládková, E. a kolektiv. 2009. Finanční účetnictvi a výkaznictví, Praha: ASPI, a.s. 2009. ISBN: 978-80-7357-434-5.

Strouhal, J. a kol.: Oceňování v účetnictví, 1. vydání, Praha : Wolters Kluwer ČR 2013. ISBN 978-80-7478-366-1.

Г. Дласкова, Університет фінансів та управління (Прага, Чехія);

€. Циповова, Ph.D., Університет фінансів та управління (Прага, Чехія);

Оцінка нематеріальних активів відповідно до стандартів бухгалтерського обліку Чехії та МСФ3 у контексті обґрунтування положень фінансової звітності

Глобалізація економіки та відкритість кордонів в процесі здійснення підприємницької діяльності зумовлює необхідність уніффікації національних стандартів складання корпоративних фінансових звітів з метою надання мультинаціональним стейкхолдерам (інвесторам, банкам, рейтинговим агенціям та інших організаціям) рівних можливостей адекватного трактування їх змісту та прийнятття ефрективних управлінських рішень на їх основі. Метою даної статті є дослідження відмінностей між Чеськими стандартами бухгалтерського обліку та Міжнародними стандартами фінансової звітності стосовно придбання та оцінки основних засобів, оцінки ступеня їх впливу на показники фрінансової звітності. У статті ідентифіковані основні види ризиків для користувачів бухгалтерської звітності, пов'язані з відмінностями їх побудови. У статті розглядаються можливі розходження отриманих значень рівня кредитоспроможності компанії, розрахованого за допомогою Z-моделі оцінки ймовірності банкрутства, внаслідок використання даних різних систем бухгалтерської звітності. Зокрема, в роботі визначено рівень кредитоспроможності компаній на основі даних звітності, побудованої за принципами Міжнародних стандартів фінансової звітності та Чеських стандартів бухгалтерського обліку. На основі аналізу фінансової звітності 20 суб'єктів господарювання зроблено висновок про суттєвий вплив системи бухгалтерського обліку на оцінку рівня кредитоспроможності компанії. Доведено, що наявність даних відмінностей може мати значний ризик для портфелю компаній, які кредитуються одним банком. Основними причинами даного впливу визнано відмінності у процедурах приведення майбутньої вартості активів до теперішньої вартості та обліку операцій лізингу, що може призвести до суттєвих відмінностей у фінансових результатах діяльності компанії, рівнях їі фінансової стабільності та ринкової вартості. Авторами проаналізовані сектори економіки з позииії їх залежності від обраного виду стандартів бухгалтерського обліку, на основі якого здійснюється оцінка фінансового стану компанії. Одним із найбільш залежних секторів економіки в цьому напрямі визнано будівельний.

Ключові слова: модель банкрутства, МСФ3, Чеські стандарти бухгалтерського обліку, модель Z-оцінки, фінансові звіти, оцінка активів. 